\title{
Wastewater from Table Olive Industries
}

\author{
G.M. Cappelletti, G.M. Nicoletti and C. Russo \\ Dipartimento SEAGMeG - University of Foggia, \\ Italy
}

\section{Introduction}

In several Mediterranean countries the production of table olives plays an important part in the national economy. Moreover, in recent years there has been a worldwide increase in the production and consumption of these olives (Figure 1). From 2003 to 2009 the major oliveproducing countries were: Spain (with an average of 503,300 tonnes per annum, representing approximately $26 \%$ of world production), Egypt (with an average of 299,600 tonnes per annum $-15.4 \%$ of world production) and Turkey (with an average of 230,800 tonnes per annum $-11.9 \%$ of world production). The major olive-consuming countries were: the USA; with an average of 217,600 tonnes per annum $-11.2 \%$ of world consumption), Spain, with an average of 197,700 tonnes per annum $-10.1 \%$ of world consumption) and Turkey (with an average of 183,700 tonnes per annum $-9.4 \%$ of world consumption).

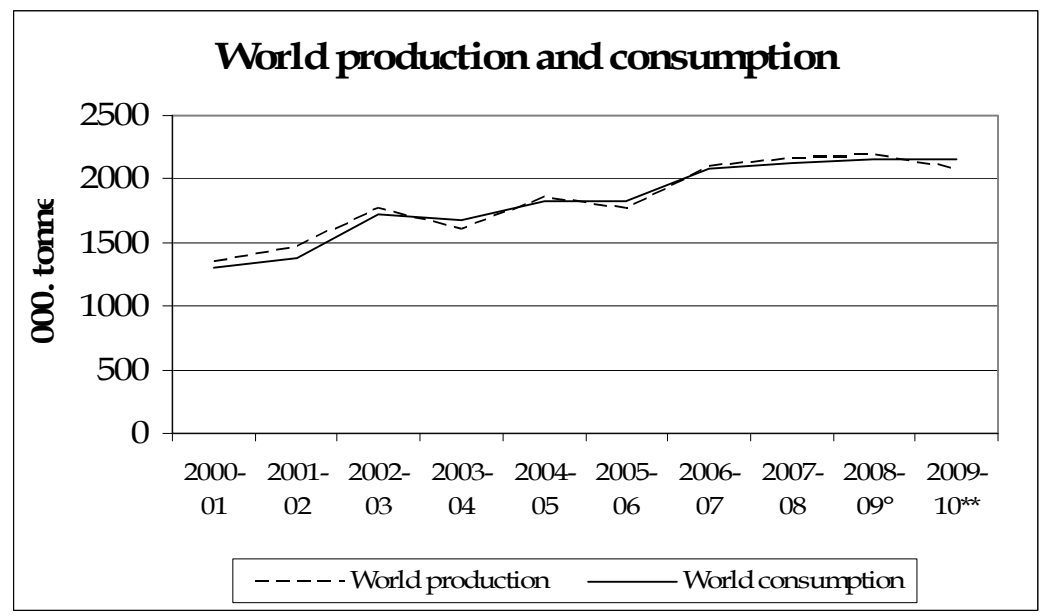

Source: www.internationaloliveoil.org

${ }^{\circ}$ provisional data ${ }^{* *}$ expected data

Fig. 1. Table olives world production and consumption

During the same period the major olive-exporting countries were: Spain (exporting an average of 181,700 tonnes per annum), Argentina (exporting an average of 65,000 tonnes per annum), Morocco (exporting an average of 63,500 tonnes per annum) and Egypt (exporting 
an average of 62,800 tonnes per annum). The countries which imported the most olives were: the USA (which imported an average of 129,600 tonnes per annum), Brazil (which imported an average of 61,400 tonnes per annum) and Russia (which imported an average of 55,800 tonnes per annum). (www.internationaloliveoil.org).

This chapter analyze the environmental aspects of table olives sector. After describing the production processes will be analyzed the characteristics of wastewaters, the pollution prevention technologies, and will be evaluate the relative environmental burdens through the LCA methodology.

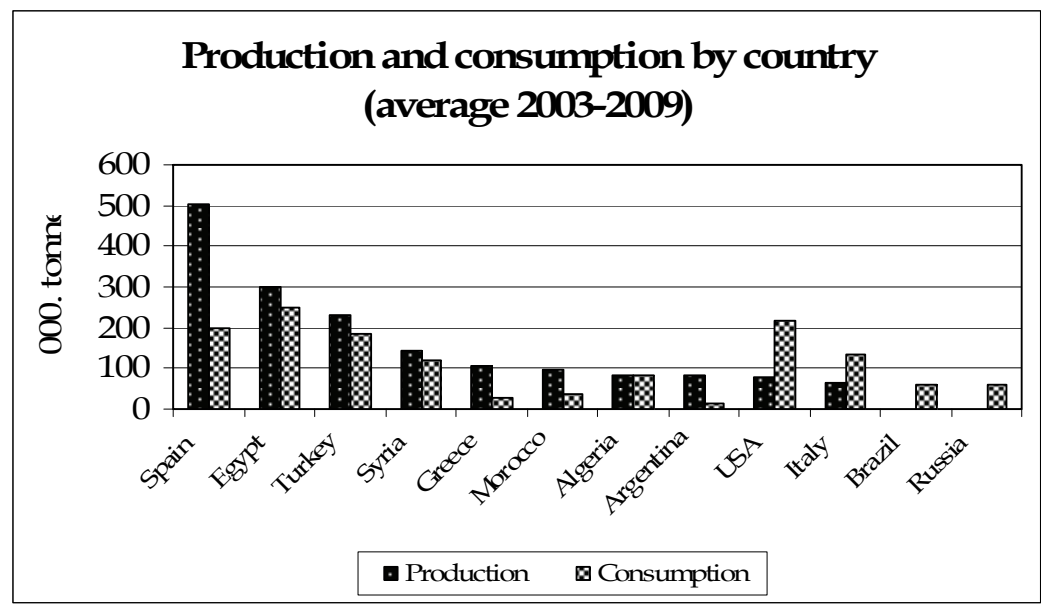

Source: www.internationaloliveoil.org

Fig. 2. Table olives world production and consumption, by distinguishing among producers countries

\section{The transformation of table olives}

The quality of olives differs from year to year and depends on various things such as climate, rainfall, the amount of pests etc. The methods used for processing olives, according to the IOOC/Codex standard, are listed in Table 1. The degree of ripeness of the drupes when they are picked varies according to the processing method that is going to be used, as does the cultivar - which in some cases has taken on the name of the main area in which the olive-variety is used.

\subsection{Green olives}

Drupes which are harvested before they are completely ripe, i.e. when they are still green, are intended for processing as "Spanish-style green olives", "Castelvetrano style green olives" or "Naturally-processed black olives".

\subsubsection{Spanish-style green olives}

The most common method for producing green olives in brine is "Spanish-style" processing. This comprises the following steps: lye treatment (debittering), rinsing, brining, fermentation in brine, packaging and pasteurization. 


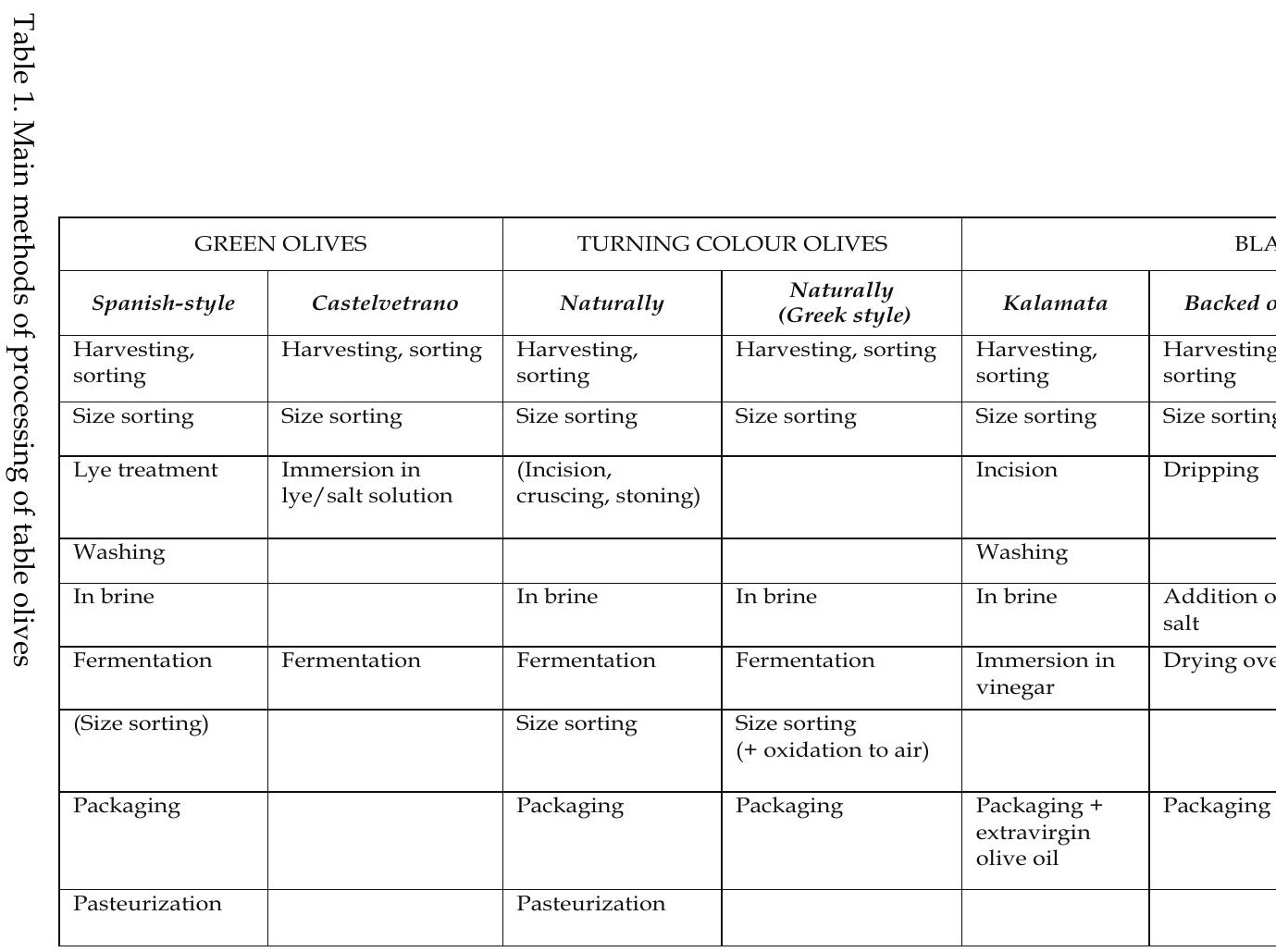


Lye treatment (Debittering).

The olives are picked when they have reached their maximum size and are green, or greenish-yellow, in colour; then - after removing any leaves, sorting the drupes and grading them according to size - the olives are treated with an alkaline lye before being immersed in brine. During this treatment the olives are put into a dilute aqueous solution of sodium hydroxide, with a concentration of $1.7 \%-4 \%(\mathrm{w} / \mathrm{v})$; the strength of the concentration depends on the olive-variety, the degree of ripeness of the drupe and the temperature and characteristics of the water used. During the preparation of the lye, the reaction that occurs is exothermic, so the olives should not be put into the solution until it has cooled down. The strength of the concentration of sodium hydroxide depends on the characteristics of the olives being processed: for example, less ripe olives with harder flesh require a higher concentration of soda.

More concentrated solutions can soften the flesh of the drupe, while more dilute solutions which slow down the debittering process - adversely affect the subsequent fermentation. During treatment the olives must be kept submerged in the solution to prevent oxidation by exposure to the air (resulting in blackening) and to avoid incomplete debittering. In addition, in order to stop the soda from collecting at the bottom of the container (which would result in a solution with varying degrees of alkalinity and thus a non-uniform softening of the drupes), the solution should be mixed and homogenized from time to time (Brighigna, 1998). This debittering phase of the process removes the oleuropein, one of the bitter glucosides naturally present in olive-flesh (Marsilio et al., 2001). The duration of the debittering process ranges from a minimum of 8 hours to a maximum of 15 hours; the treatment is considered complete when the $\mathrm{NaOH}$ solution has penetrated from $2 / 3$ to $3 / 4$ of the way into the olive-flesh. Traditionally olives have been treated using fresh lye, but it is possible to re-utilize exhausted lye and thus lower pollution levels (Garrido-Fernandez, 1997; Segovia-Bravo et al., 2008).

Rinsing.

The reason for rinsing the olives with water is to remove most of the lye from the flesh. This phase is very significant from an environmental point of view because it entails the use of large quantities of fresh water, with the consequent production of the same amounts of waste water which contains polluting compounds (Brenes, 2005).

The rinses may be:

- of long-duration: for olives which are meant to be consumed within a short period of time, or for those which are processed as semi-fermented olives; this method involves changing the rinsing water every 8-10 hours for a total duration of 4-5 days in order to obtain an almost clear liquid;

- of medium duration: this is the most commonly-used method. After a first rather short rinse lasting 1-2 hours there are then another 2 rinses lasting 8-12 hours each, resulting in a total of 18-25 hours of rinsing-time. In this case the olives retain enough fermentable substances to ensure proper lactic fermentation;

- of short duration: this consists of a single rinse lasting about 15 hours. With this method the large amount of $\mathrm{NaOH}$ solution left in the fruit prevents the rapid onset of lactic fermentation, and sometimes encourages abnormal fermentation. To ensure proper fermentation it is necessary to replace the used brine with fresh, resulting in the consumption of large quantities of fresh water. The elimination of the "brine mother", 
however, results in the loss of important components such as fermentable substances, minerals, etc.;

- neutralizing rinses: the aim of this phase is to neutralize the alkalinity of the olives using organic acids (citric acid, ascorbic acid, acetic acid) or inorganic (hydrochloric) acid, or by means of the insufflation of micronized $\mathrm{CO}_{2}$ into the brine. This procedure reduces water consumption and shortens processing time, while conserving most of the fermentable substances and encouraging a rapid onset of lactic fermentation. Some researchers have looked into the possibility of replacing the traditional rinses with a process which neutralizes the residual alkali using organic or inorganic acids (Brighigna, 1998; Garrido-Fernandez, 1997; Higinio Sánchez Gómez, 2006).

Fermentation in brine.

After rinsing or neutralization, the olives are placed in suitable containers and covered with brine that has a $\mathrm{NaCl}$ concentration starting at $9-10 \%$ but decreasing rapidly to around $5 \%$, because of the high water content of the olives. Fermentation helps to preserve the product and improve its taste.

It is also possible to add used brines which have been previously analyzed; these are the socalled "brine mothers" which ensure the onset of safe lactic fermentation.

The expression 'onset of fermentation' means the moment when the brine has arrived spontaneously at a $\mathrm{pH}$ value of around neutral $( \pm 7)$, while the fermentation process is deemed complete when, after 2-3 months, the olives are pale yellow in colour and have good texture and a pleasantly-sour taste. If more than 6 months lapses between the stage of fermentation and that of packaging, it is necessary to add salt to the solution in order to stabilize the brine at a concentration ranging from $8 \%$ to $10 \%$ (Arroyo-López, 2008; Brenes, 2004; Gomez et al., 2006; Garrido-Fernandez, 1997; Hernandez, 2007; Higinio Sánchez Gómez, 2006; Quintana, 1997; Romeo, 2009).

Packaging and pasteurization.

At the end of the production process, the olives are packaged and then pasteurized to prevent progressive deterioration. This operation involves a series of procedures. After the olives are rinsed with fresh water, they are lightly blanched using steam. Then, after sorting to remove any damaged or otherwise defective olives, the containers are filled. The concentration of the brine used for packaging can vary from $3 \%$ to $5 \%$, and the $\mathrm{pH}$ value must be less than 4.6. After the containers are sealed, they are pasteurized at $90^{\circ} \mathrm{C}$ for about an hour. (Brighigna, 1998; Javier Casado, 2007; Javier Casado, 2010; Unal. \& Nergiz, 2003).

\subsubsection{The "Castelvetrano" method}

The "Castelvetrano" method, using the olive-variety known as "Nocellara del Belice" (typically grown in the Castelvetrano area of Sicily, in Italy, after which the method is named), is used for preparing olives in soda. During this method of preparation, olives which have already been cleaned and size-graded are placed in a solution of water, soda (1.8 $-2.5 \%)$ and salt (3-5\%). This procedure enables a rapid sweetening of the drupes, which retain a good consistency, a green colour and a distinctive taste of lye due to the $\mathrm{NaOH}$ solution (between $0.3 \%$ and $0.5 \%$ ) which is left in the flesh. After 10 to 15 days of debittering treatment, the olives are subjected to a brief rinse using water or brine. The shelf-life of these olives is linked to their $\mathrm{pH}$ value, which after 2-3 months tends to go down and thus encourage the development of harmful microorganisms. After packaging, the product 
should be sterilized in an autoclave at temperatures of about $120^{\circ} \mathrm{C}$, to prevent the formation of Clostridium Botulinum and the subsequent production of the Botulin toxin (Brighigna, 1998).

\subsubsection{The method used for producing "Naturally-processed green olives"}

"Naturally-processed green olives" can be prepared in various ways: whole, crushed, stoned, dressed or flavoured with spices. However, in all these cases the debittering process is carried out naturally, without any form of chemical intervention during the deamarization. In general, it takes at least 10-12 months of fermentation and storage in order to end up with a high-quality product, but there are some varieties of olive which are naturally sweet and require less time (Amelio \& De Muro, 2000). The product is preserved in brine, the concentration of which is kept stable between $8 \%$ and $10 \%$. The length of the sweetening process depends on several factors such as olive-variety, the amount of oleuropein (a bitter glycoside) in the fruits, the ripeness of the olives and the area where they were grown. The finished product is pleasantly bitter, with a slight winey taste due to the fermentation of the sugar components in the flesh of olives.

The only wastewaters produced during this "natural" fermentation are the rinsing water and the brine. In order to reduce pollution, the brine can be regenerated and re-utilized (Garrido-Fernandez, 1997; Quintana, 1997).

\subsection{Black olives}

Black olives, which are picked when they are almost fully ripe, may be processed by various methods. In general, the olive-varieties that are grown to be processed as black olives are those whose drupes have a thin peel, flesh with a good consistency and a very good colour, as well as a good flesh-to-pit ratio. When the olives are "naturally processed" in brine, the technology is not very different from that used for green olives (as described above), and the only real difference lies in the organoleptic characteristics of the finished product. However, while the method used for processing "Californian-style" black olives is similar to that used for "Spanish-style" green olives, the amount of alkali, the number of rinses and the colourfixing stage are all different.

\subsubsection{The "Californian-style" method (ripe table olives)}

The product of this processing method, originally from California, is thus defined by the US Department of Agriculture: "Olives treated and oxidized during processing, in such a way that they assume a characteristic colour that ranges from dark brown to black, are called 'ripe table olives'". These olives, picked when partially or fully ripe, are first sorted and sizegraded.

Storage in brine.

Before treatment with a $\mathrm{NaOH}$ solution, the olives are stored in brine at a concentration of between $8 \%$ and $10 \%$ for at least 30 days. The olives are preserved either in an acid solution ( $0.4 \%$ lactic acid) or by refrigeration (Gomez et al., 2006).

Lye treatment (Debittering)

The original processing method requires repeated debittering treatments (usually three) with a solution of $1 \%-2 \%$ sodium hydroxide, with each treatment lasting between 2 and 6 hours. During the rinsing phases, between one lye treatment and the next, insufflations of 
air into the water enable the olives to be thoroughly mixed. This helps to darken the surface of the fruit and encourages the enzymatic oxidation of the phenolic compounds present in it. These days the larger olive-processing firms, in order to simplify production, prefer a single treatment using a sodium solution at a concentration of between $1.2 \%$ and $1.5 \%$, until the soda has completely penetrated the flesh of the drupes. Agitators or pumps are employed to mix the solution and prevent the soda collecting at the bottom of the container (Brenes, 2004; Higinio Sánchez Gómez, 2006).

The "Californian-style" method has a variant which uses only one debittering treatment with a lye solution at a concentration that ranges from $1.3 \%$ to $2.5 \%$. The alkaline treatment is stopped when the lye has penetrated about $2 / 3$ of the way into the flesh of the olives.

Rinsing between treatments

The rinsing, which has to be carried out between the various lye treatments, leads to a significant consumption of fresh water. As mentioned above, the rinses have the dual function of removing the sodium left in the olives and oxidizing them. Olives processed using the variant of this method (with its single debittering treatment) should undergo more rinses. It is also advisable to use lactic acid to sweeten the product and improve its chemical stability.

Immersion in a ferrous salt solution

After the lye treatment, the drupes are immersed for 12-24 hours either in a ferrous gluconate solution $(1-2 \mathrm{~g} / \mathrm{L})$ or in a ferrous lactate solution $(0.5-1 \mathrm{~g} / \mathrm{L})$. The aim of this phase is to give the olives a uniformly black colour which will be permanent (Brighigna, 1998; Garrido-Fernandez, 1997; Higinio Sánchez Gómez, 2006).

Final rinsing

After immersion in a ferrous salt solution, the olives are rinsed several times (from a minimum of 2 to a maximum of 8 ) until the rinsing water is $\mathrm{pH}$ neutral. Sometimes the water is heated to $80^{\circ} \mathrm{C}$ to prevent softening of the flesh and its consequent "fish eye" deterioration (caused by gas pockets). Once the rinsing water is $\mathrm{pH}$ neutral (after at least 2 rinses) there may be an optional phase of exposing the olives to air for 2-3 days, followed by a further size-grading.

Packaging and sterilization

These olives are usually packaged in brine with $2-5 \% \mathrm{NaCl}$ and a $\mathrm{pH}$ of $<4.6$. The packaging procedures are basically the same as those for "Spanish-style green olives", described above. The only significant difference is the composition of the brine: in the "Californian-style" method this has a lower salt concentration and a higher $\mathrm{pH}$ value, which together create favourable conditions for the development of pathogenic germs and airborne or sporulate bacteria (such as Clostridium botulinum) - with serious consequences both for the consumer and for the product itself. It is therefore necessary to sterilize the containers by subjecting them to temperatures of $121^{\circ} \mathrm{C}$ for about an hour. After this heat treatment, samples from each batch should be subjected to microbiological controls in a specialized laboratory. It must be said, however, that sterilization affects the organoleptic properties of olives. Moreover, in some olives treated in this way, the flesh becomes less firm. (Kanavouras, 2005). The injection of calcium chloride (1 kg per $100 \mathrm{~kg}$ of olives) into the final wash may help to maintain the consistency of the drupes; any use of this additive, however, must be explicitly mentioned as 'E 509' on the label of the container. 


\section{Chemical characteristics of the wastewater from table olives processing}

The production of table olives (green, naturally black etc.) involves various and consistent flows of wastewater (from min 0.5 liters $/ \mathrm{kg}$ to 6 liters $/ \mathrm{kg}$ ). Every year, in the world from almost 1 million to almost 11.7 million tons of wastewater are generated from the processing of 1.9 million tons of table olives (assessment done by the author on the 2003-2009 average data coming from IOC, International Olive Council). Table 2 shows the production and assessment of the wastewater generated from the table olive processing, distinguishing for Country. The number of flows and their respective volumes are different and they depend of the kind of finished product. In order to have a picture more complete, the wastewater deriving from the washes of the container and those used for the packaging should be added to the amount indicate in the table 3 . The processing of table olives dates back to a lot of years ago, so the industries never considered the availability of the water as resource and the environmental effects deriving from its use. The processing of table olives is an activity concentrated in a few months per year (in particular autumn-winter) and in restricted geographic areas (sometimes with little surface water resources). This determines strong pressure on the water resources and on the quality of the surface water.

Before that these problematic were pointed out with particular gravity, relevance wasn't been given to the surface sampling, or at the ground and at the draining modality of the wastewater. The growing attention towards the use of natural resources and the arising of the national laws and, in the case of Europe Union, of community laws ever more constricting for what concerning the draining of wastewater, involve the needing to assess with attention the modality of the water use into the table olives production processes.

\begin{tabular}{|l|c|c|c|c|c|c|c|c|c|c|c|}
\cline { 2 - 12 } \multicolumn{1}{c|}{} & \multicolumn{10}{c|}{ Countries } \\
\cline { 2 - 12 } \multicolumn{1}{c|}{} & ES & EG & TR & SY & GR & MA & DZ & AR & USA & IT & Others \\
\hline Production & 503.3 & 299.6 & 230.8 & 143.3 & 108.2 & 98.3 & 81.9 & 80.8 & 79.7 & 65 & 249 \\
\hline $\begin{array}{l}\text { Estimated } \\
\text { wastewater } \\
(\text { min) }\end{array}$ & 252 & 150 & 115 & 72 & 54 & 49 & 41 & 40 & 40 & 32 & 125 \\
\hline $\begin{array}{l}\text { Estimated } \\
\text { wastewater } \\
\text { (max) }\end{array}$ & 3020 & 1798 & 1385 & 860 & 649 & 590 & 491 & 485 & 478 & 390 & 1494 \\
\hline
\end{tabular}

Source: Author estimation based on data COI

Table 2. Table olives production and estimated waste water (average 2003-2009) (1,000 tonnes)

\begin{tabular}{|l|c|c|c|c|c|}
\hline $\begin{array}{l}\text { Table olive processing } \\
\text { methods }\end{array}$ & Lye & $\begin{array}{c}\text { Fermentation } \\
\text { brine }\end{array}$ & Washing & $\begin{array}{c}\text { Preservation } \\
\text { brine }\end{array}$ & Total \\
\hline Spanish style & 0.5 & 0.5 & $0.5-2.0$ & 0.5 & $2-3.5$ \\
\hline $\begin{array}{l}\text { Untreated green and turning } \\
\text { colour olives }\end{array}$ & 0.5 & & 0.5 & 1 \\
\hline California green ripe olives & 0.5 & 0.5 & $0.5-2.0$ & $0.0-0.5$ & $1.5-3.5$ \\
\hline California black ripe olives & $0.5-2.5$ & 0.5 & $0.5-3.0$ & 0.5 & $2-6.5$ \\
\hline Naturally black olives & & 0.5 & & 0.5 & 1 \\
\hline
\end{tabular}

Source: Garrido-Fernandez et al, 1997

Table 3. Volume (L) of wastewater per kg of olives produced during the main phases of different types of table olives. 
The problem can be cope with different and complementary ways:

- By trying to decrease the entire water requirement in the process (by reduction of the volume used in the single step of the process, exclusion of some operations from the process or reduction of its number, reuse of the same water on the same operation but on different batches of table olives;

- By trying to reduce the environmental impact of the wastewater (low percentage of $\mathrm{NaOH}$ in the lye or $\mathrm{NaCl}$ in the fermentation brine);

- $\quad$ By setting specific wastewater treatment methods.

The approaches listed above in point 1 and 2 are process improvements, while, the wastewater treatment is not affected by modifies applied to the processing method.

All these approaches were been studied in the last ten years. However, before to analyzing the most important results, it could be useful to watching the chemical characteristics of the wastewater generated by the various processes.

\subsection{Wastewater from Spanish-style green olives processing}

The approximate characteristics of the wastewaters from this treatment of the green olives are reported in the table 4 .

\begin{tabular}{|l|c|c|c|}
\hline \multicolumn{4}{|c|}{$\begin{array}{c}\text { General characteristics of wastewaters from processing } \\
\text { Spanish-style pickled green olives in brine }\end{array}$} \\
\hline Characteristic & Lye & Washing water & Fermentation brine \\
\hline $\mathrm{pH}$ & $9.5-12.0$ & $9.0-11.5$ & $3.8-4.2$ \\
\hline Free $\mathrm{NaOH}(\mathrm{g} / \mathrm{L})$ & 11.0 & 1.5 & - \\
\hline Free acidity (g lactic acid/L) & - & - & $6-15$ \\
\hline Polyphenols (g tannic acid/L) & $2.5-4.0$ & $2.5-4.0$ & $4.0-6.0$ \\
\hline Reducing sugars (g glucole /L) & $6-9$ & $6-9$ & - \\
\hline Dissolved organic solids (g/L) & $20-30$ & $20-30$ & $15-25$ \\
\hline Dissolved inorganic solids (g/L) & $20-35$ & $7-25$ & $90-110$ \\
\hline COD $\left(\mathrm{g} \mathrm{O}_{2} / \mathrm{L}\right)$ & $15-35$ & $12-35$ & $10-35$ \\
\hline BOD $\left(\mathrm{g} \mathrm{O}_{2} / \mathrm{L}\right)$ & $9-20$ & $9-20$ & $8-20$ \\
\hline
\end{tabular}

Source: Garrido-Fernandez et al, 1997

Table 4. Characteristics of the wastewater from Spanish-style green olives processing

All these wastewaters are highly polluting and are not simply treated by conventional methods. As it can be seen, there are two different groups of wastewaters, alkaline (lye and washing waters) and acidic (fermentation brine). Their management and treatment need to be separate and different.

Lye and washing water noticeable differ in residual alkali concentration, and, in minor amount, in dissolved inorganic solids. The content of polyphenols is higher in the fermentation brine, while is null the one of reducing sugars.

Longer is the contact time between fruits and solution in each step greater are the dissolved substances. So, if it is good to dissolve the greatest amount of polyphenols, it is not good to extract reducing sugars during the lye treatment and washing. They are necessary during the successive fermentation step.

The brine' main characteristic is the high concentration of inorganic components (mainly $\mathrm{Na}$ and $\mathrm{K}$ salts). They come from the added $\mathrm{NaCl}$ and from the high content of the olive flesh. The contemporary presence of substances easily used by microbes as carbon sources (reducing sugars in lye and washing waters, lactic acid in brine where it accounts for about 
$80 \%$ of the $\mathrm{BOD}_{5}$ ), and substances that interfere with them (polyphenols), seriously interfere with the direct application of any biological purification procedure.

In conclusion, these wastewaters are heavily polluted, perhaps difficult to treat and dispose of. Many strategies have been studied to reduce the environmental impact of these wastewaters: internal control measures, such as lye and washing waters re-use, reduction or elimination of washing waters, debittering with low-concentration lyes, regeneration and reuse of fermentation brine. Any of these approaches has completely resulted in meeting the needs (Garrido-Fernandez et al., 1997).

Table 5 shows the value, expressed in grams per litre of oxygen, biological oxygen demand $\left(\mathrm{BOD}_{5}\right)$ and chemical oxygen demand (COD) of wastewater processing from Spanish-style.

\begin{tabular}{|c|c|c|c|c|c|c|c|c|c|c|c|c|c|c|}
\hline 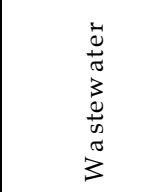 & $\frac{T}{2}$ & 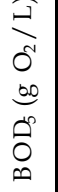 & $\begin{array}{c}\stackrel{\Im}{\ominus} \\
\underbrace{0}_{0} \\
0 \\
0\end{array}$ & 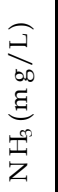 & $\begin{array}{l}\underset{\Xi}{\Xi} \\
\underset{00}{\Xi} \\
\Xi\end{array}$ & $\begin{array}{l}\mathcal{\Xi} \\
\underset{00}{\Xi} \\
\Xi \\
a\end{array}$ & 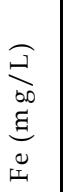 & 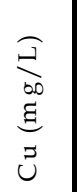 & 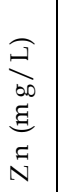 & 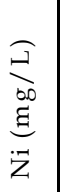 & $\begin{array}{l}\text { త } \\
\underset{00}{0} \\
\Xi \\
\pm \\
I\end{array}$ & $\underset{\widetilde{\sigma}}{\stackrel{\oplus}{\rightleftharpoons}}$ & $\underset{\underbrace{}}{\stackrel{Ð 0}{\Xi}}$ & $\begin{array}{l}\mathcal{\Xi} \\
\underset{00}{\Xi} \\
\Xi \\
\frac{1}{U}\end{array}$ \\
\hline Lye & 12.7 & 4.8 & 24.0 & 1.3 & 0.14 & 18.3 & 5.75 & 0.23 & 0.48 & 0.12 & 0.08 & 96.5 & 18.5 & 2.9 \\
\hline 1st Washing & 9.1 & 3.1 & 10.0 & 16.8 & 0.63 & 28.4 & 3.62 & 0.16 & 0.36 & 0.09 & 0.05 & 15.7 & 4.2 & 1.9 \\
\hline 2nd Washing & 7.6 & 1.6 & 7.6 & 1.3 & 0.40 & 16.3 & 1.54 & 0.10 & 1.64 & 0.03 & 0.05 & 10.5 & 2.6 & 1.1 \\
\hline 3rd Washing & 6.2 & 0.9 & 3.0 & 2.0 & 0.34 & 11.4 & 0.84 & 0.06 & 0.08 & 0.02 & 0.09 & 5.0 & 1.7 & 0.7 \\
\hline 4th Washing & 6.5 & 0.6 & 2.0 & 2.3 & 0.28 & 10.6 & 0.82 & 0.04 & 0.07 & 0.01 & 0.06 & 3.7 & 1.1 & 0.5 \\
\hline 5th Washing & 7.0 & $<0.1$ & 0.2 & 3.5 & 0.16 & 4.8 & 0.40 & $<0.01$ & 0.12 & 0.01 & 0.05 & 1.1 & 0.3 & 0.2 \\
\hline
\end{tabular}

Source: Garrido-Fernandez et al, 1997

Table 5. Loads polluting wastewater processing of green olives by the "Spanish-style"

\subsection{Wastewater from turning colour olives processing}

Processes not based on an alkaline treatment, comprising only fermentation or storage brine and, sometimes, water from washing before packing, produce a less volume of wastewaters that are less contaminated.

\begin{tabular}{|c|c|c|c|c|c|c|c|c|}
\hline \multicolumn{9}{|c|}{ Main wastewaters from a typical darkening stage } \\
\hline \multirow{2}{*}{ Characteristic } & \multirow{2}{*}{$\begin{array}{l}\text { Holding } \\
\text { brine }\end{array}$} & \multicolumn{2}{|c|}{$1^{\text {st }}$ treatment } & \multicolumn{2}{|c|}{$2^{\text {nd }}$ treatment } & \multicolumn{2}{|c|}{$3^{\text {rd }}$ treatment } & \multirow{2}{*}{$\begin{array}{c}\text { Gluconate } \\
\text { solution }\end{array}$} \\
\hline & & Lye & Wash & Lye & Wash & Lye & Wash & \\
\hline $\mathrm{pH}$ & - & 12.11 & 6.90 & 11.85 & 8.00 & 11.70 & 8.55 & 3.70 \\
\hline Free $\mathrm{NaOH}(\mathrm{g} / \mathrm{L})$ & - & 8.90 & - & 4.60 & - & 4.30 & - & - \\
\hline $\begin{array}{l}\text { Dissolved inorganic } \\
\text { solids }(\mathrm{g} / \mathrm{L})\end{array}$ & - & 2.38 & 3.18 & 4.34 & 7.21 & 6.88 & 8.14 & 7.33 \\
\hline $\begin{array}{l}\text { Dissolved organic } \\
\text { solids }(\mathrm{g} / \mathrm{L})\end{array}$ & - & 19.27 & 3.15 & 12.25 & 32.21 & 12.08 & 36.64 & 43.38 \\
\hline Polyphenols (g/L) & - & 0.18 & 0.22 & 0.59 & 0.31 & 0.48 & 0.64 & 0.80 \\
\hline $\mathrm{COD}\left(\mathrm{g} \mathrm{O}_{2} / \mathrm{L}\right)$ & 35.0 & 2.0 & 3.5 & 2.5 & 3.8 & 2.6 & 3.7 & 1.5 \\
\hline
\end{tabular}

Table 6. Characteristics of the wastewater from turning color olives processing 
Process that includes alkali treatment and the darkening stage (by the use of ferrous gluconate) (California-style method), needs a greater volume of water, due mainly to the numerous lye treatments and washes (Table 6).

It can be seen that the highest pollutant charge comes from the holding brine, while lyes and washing waters are relatively moderate. Fermentation-storage brine has characteristics very similar to those from Spanish-style green olives (Garrido-Fernandez et al, 1997).

\subsection{Wastewater from naturally black olives processing}

Fermentation brines are the only waste liquids produced during this type of processing that pose some problem. They are liquids with a high level of organic matter (Table 7).

\begin{tabular}{|l|c|}
\hline Characteristics & Brines from different origins \\
\hline $\mathrm{pH}$ & $3.6-4.4$ \\
\hline Salts $(\mathrm{g} \mathrm{NaCl} / \mathrm{L})$ & $56.0-77.0$ \\
\hline Dissolved organic solids $(\mathrm{g} / \mathrm{L})$ & $95.3-118.8$ \\
\hline $\mathrm{BOD}_{5}\left(\mathrm{~g} \mathrm{O}_{2} / \mathrm{L}\right)$ & $34.8-38.3$ \\
\hline Polyphenols $(\mathrm{g} / \mathrm{L})$ & $3.2-5.1$ \\
\hline
\end{tabular}

Table 7. Characteristics of the wastewater from naturally black olives processing

It is the highest between all types of table olives processing, very close to those reached in olive oil mill wastewaters. The molecules contained in the organic matter of these brines, however, are only heavy potential contaminants, as shown by their high $\mathrm{BOD}_{5}$.

The salt content is higher than in any other process. Such concentrations can cause serious problems for conventional municipal wastewater treatment facilities.

\subsection{Wastewater from black olives by Californian - style}

Tables 8 and 9 show the values of $\mathrm{BOD}_{5}$ and $\mathrm{COD}$ of wastewater processing of black olives by Californian-style and its variant, table 10 the values of TOC of packing brines of Spanish-style and Californian-style, and Table 11 the characteristic of Californian style wastewater.

\begin{tabular}{|c|c|c|}
\hline Wastewaters & $\mathrm{BOD}_{5}\left(\mathrm{mgO}_{2} / \mathrm{L}\right)$ & $\mathrm{COD}\left(\mathrm{mgO}_{2} / \mathrm{L}\right)$ \\
\hline Preservation & 10,620 & 35,000 \\
\hline $1^{\text {st }}$ Lye treatment & 607 & 2,000 \\
\hline 1 st Washing & \begin{tabular}{l|l}
1,062 \\
\end{tabular} & 3,500 \\
\hline 2nd Lye treatment & 759 & 2,500 \\
\hline 2nd Washing & 1,153 & 3,800 \\
\hline $3^{\text {rd }}$ Lye treatment & 789 & 2,600 \\
\hline 3rd Washing & 1,123 & 3,700 \\
\hline Immersion in ferrous salt solution & 455 & 1,500 \\
\hline $4^{\text {th } W a s h i n g}$ & 394 & 1,995 \\
\hline $5^{\text {th }}$ Washing & 394 & 1,995 \\
\hline
\end{tabular}

Source: Garrido-Fernandez et al, 1997

Table 8. Pollution loads of wastewater from processing of black olives processed by the Californian style 


\begin{tabular}{|c|c|c|}
\hline Wastewaters & $\mathrm{BOD}_{5}\left(\mathrm{mgO}_{2} / \mathrm{L}\right)$ & $\mathrm{COD}\left(\mathrm{mgO}_{2} / \mathrm{L}\right)$ \\
\hline 1 st Lye treatment & 150 & 4,260 \\
\hline 1 st Washing & 230 & 6,210 \\
\hline 2nd Washing & 200 & 3,880 \\
\hline 3 rd Washing & 190 & 1,480 \\
\hline 4 th Washing & 190 & 1,680 \\
\hline 5 th Washing & 294 & 2,950 \\
\hline $6^{\text {th }}$ Washing + lactic acid & 336 & 5,550 \\
\hline $7^{\text {th }}$ Washing + lactic acid & 200 & 5,840 \\
\hline 8 th Washing + lactic acid & 434 & 5,580 \\
\hline Immersion in ferrous salt solution & 313 & 6,650 \\
\hline 9 th Washing & 430 & 2,320 \\
\hline 10 th Washing & 357 & 1,670 \\
\hline
\end{tabular}

Table 9. Pollution loads of wastewater from black olive processing by variant of the Californian style

\begin{tabular}{|l|r|r|}
\hline Preservation brine & Green olives & \multicolumn{1}{|c|}{ Black olives } \\
\hline TOC $(\mathrm{mg} / \mathrm{L})$ & 3,089 & 3,368 \\
\hline
\end{tabular}

Table 10. Loads of pollutants brines packaging, expressed as total organic carbon (TOC)

\begin{tabular}{|c|c|}
\hline \multicolumn{2}{|c|}{ "Californian Style" wastewater } \\
\hline Method A & COD \\
\hline 1 st Lye treatment & 2,000 \\
\hline 1 st Washing & 3,500 \\
\hline 2 nd Lye treatment & 2,500 \\
\hline 2nd Washing & 3,800 \\
\hline 3 rd Lye treatment & 2,600 \\
\hline 3 rd Washing & 3,700 \\
\hline Immersion in ferrous salt solution & 1,500 \\
\hline 4 th Washing & 1,995 \\
\hline $5^{\text {th }}$ Washing & 1,995 \\
\hline
\end{tabular}

Source: Garrido-Fernandez et al, 1997

Table 11. Characteristic of Californian style wastewater

\section{Pollution prevention methods in the table olive industries}

Prevention is better than curing. So internal control measures of potential pollutants or water use must be preferred as the first choice to tackle the environmental impacts of these industries. 
Internal control measures include:

- $\quad$ Re-use of lye, washing waters, fermentation/storage brine;

- Reduction or elimination of washing waters;

- Debittering with low-concentration lyes;

- $\quad$ Salt-free storage solution.

Notwithstanding many experimental studies fulfilled during the latter decades, no one has produced results totally sharable, so, not even one was introduced as process improvement. This because, each modify, introduced respect to the traditional process, ever involves variations in the quality of the product which aren't accepted. As was noted, the chemical composition of the table olive wastewaters limits the effectiveness of classical purification systems. Polyphenols (oleuropein and derivates, anthocyanins) and sodium content (from the $\mathrm{NaOH}$ in the lye and from $\mathrm{NaCl}$ in the brines) are the most important pollutants contained.

Accordingly, in the latter years a number of studies were carried out in order to adapt these wastewaters to the limits accepted by the national environmental laws (Deligiorgis et al., 2008).

Purification (partial) of lyes and washing waters from green table olives processing by lowering the $\mathrm{pH}$ under the neutrality and by leading the temperature of the wastewater around $0^{\circ} \mathrm{C}$ (De Castro et al., 1983), allow to bring COD down over 35\%. The wet oxidation carried out in alkaline environment into a pressurized reactor, at the temperature of $200^{\circ} \mathrm{C}$, is able to eliminate almost all over the polyphenols, and if the pure oxygen is used, also the $90 \%$ of the organic carbon present at beginning.

The efficiency is lower when the same methods are applied to the washing waters from the darkening process of black-ripe olives. Fermentation brine represents more than the $22 \%$ of the total final wastewaters from green table olives processing, but account for approximately $70 \%$ of the organic pollution charge. Thus, if these brines are correctly purified much of the pollution potential is eliminated. Physicochemical treatment reduce the pollutant charge (COD) of the fermentation brines only about $20 \div 25 \%$.

There is not much experience of biological treatment to remove the excess organic charge up to now (Beltran et al., 2008). The main problem is related to polyphenols degradation and the salt level; appropriate dilution and/or adapted microorganisms are needed. Brenes et al. showed that an activated sludge process can be used successfully, yealding a $80 \%$ COD reduction, but only a small proportion of polyphenols was consumed. A manner to reduce the polyphenols content could be the wet air oxidation (Brenes et al., 2000; Beltràn et al., 2000a; Katsoni et al., 2008).

The best results were obtained at acidic $\mathrm{pH}$, catalized by means of $\mathrm{Cu}_{2}+$. The addition of $\mathrm{H}_{2} \mathrm{O}_{2}$ in the absence of copper resulted in a lower COD conversion, while an increase in the biodegradability of the final mixture was found after having added the radical promoter.

Kotsou et al. studied an aerobic biological treatment using an Aspergillus niger strain, in combination with chemical oxidation $\left(\mathrm{H}_{2} \mathrm{O}_{2}\right)$, followed by coagulation with $\mathrm{CaO}$ of the resulting treated waters. The results of the experiments are shown in the Table 12 (Kotsou et al., 2004).

The main effect of the chemical oxidation step was the elimination of persistent phenolic compounds during the biological treatment of total phenolic compounds. 


\begin{tabular}{|c|c|c|c|c|c|c|c|}
\hline \multicolumn{2}{|c|}{ Influent } & \multicolumn{2}{|c|}{$\begin{array}{c}\text { After the biological } \\
\text { step } \\
\text { HT } 2 \text { days }\end{array}$} & \multicolumn{2}{|c|}{$\begin{array}{c}\text { After chemical } \\
\text { Oxidation }\left[\mathrm{H}_{2} \mathrm{O}_{2}\right] \\
4 \mathrm{~g} / \mathrm{L}\left[\mathrm{Fe}^{2+}\right] 0.5 \mathrm{~g} / \mathrm{L}\end{array}$} & \multicolumn{2}{|c|}{$\begin{array}{c}\text { Affluent after } \\
\text { liming CaO } \\
5 \mathrm{~g} / \mathrm{L} \text { Sed. Time } 2 \mathrm{~h}\end{array}$} \\
\hline $\begin{array}{l}\mathrm{COD} \\
\mathrm{mg} / \mathrm{L}\end{array}$ & $\begin{array}{c}\text { Phenols } \\
\mathrm{mg} / \mathrm{L}\end{array}$ & $\begin{array}{l}\text { COD } \\
\mathrm{mg} / \mathrm{L}\end{array}$ & $\begin{array}{c}\text { Phenols } \\
\text { mg/L }\end{array}$ & $\begin{array}{l}\mathrm{COD} \\
\mathrm{mg} / \mathrm{L}\end{array}$ & $\begin{array}{c}\text { Phenols } \\
\text { mg/L }\end{array}$ & $\begin{array}{l}\text { COD } \\
\mathrm{mg} / \mathrm{L}\end{array}$ & $\begin{array}{c}\text { Phenols } \\
\text { mg/L }\end{array}$ \\
\hline 11000 & 190.7 & 3950 & 62.4 & 1537 & 32.4 & 835 & 5.4 \\
\hline 11130 & 185.5 & 4043 & 64.7 & 1625 & 29.5 & 825 & 5.1 \\
\hline 9300 & 150.8 & 3575 & 38.1 & 1327 & 25.7 & 790 & 4.8 \\
\hline 8500 & 147.9 & 3616 & 39.6 & 1452 & 17.4 & 890 & 4.3 \\
\hline 20920 & 319.5 & 5185 & 187.5 & 2225 & 63.2 & 1675 & 21.2 \\
\hline 9750 & 157.8 & 3275 & 30.7 & 1297 & 27.3 & 675 & 4.3 \\
\hline 9080 & 152.2 & 2135 & 33.2 & 1050 & 16.9 & 780 & 4.6 \\
\hline 8190 & 137.4 & 2700 & 32.3 & 1027 & 11.8 & 795 & 3.4 \\
\hline 9960 & 178.3 & 2160 & 41.6 & 1097 & 20.1 & 835 & 3.8 \\
\hline 9850 & 185.3 & 2227 & 37.4 & 1105 & 22.7 & 895 & 3.5 \\
\hline
\end{tabular}

Source: Kotsou et al., 2004

Table 12. Characteristics of the wastewater after aerobic biological treatment

Beltran et al. studied the purification efficacy of the aerobic and anaerobic biodegradation of the wastewater from green table olive processing using acclimatized bacterial flora taken from, respectively, an activated sludge from a municipal wastewater treatment plant and a biomass from an anaerobic digester of a municipal wastewater treatment plant.

The aerobic biodegradation a significative reduction of the COD between $50 \%$ and $70 \%$, and an important removal of the total polyphenolic compounds around 97\%; the anaerobic digestion achieves an important removal of COD between 81 and 94\%, indicating that most of the substrate fed to the digester is biodegraded anaerobically (Beltran et al., 2008).

Different chemical oxidants, alone and combined, were applied to the purification of the wastewaters from the storage in brine of black table olives. The most effective purification process was the overall combination $\mathrm{O}_{3} / \mathrm{UV} / \mathrm{H}_{2} \mathrm{O}_{2}$. Aerobic treatment of the effluents gave a major substrate removal that was independent of the initial biomass concentration. The chemical treatments in general, and ozonation processes in particular, are useful for the degradation of organic matter, especially aromatic compounds.

These processes can be used as pre-treatment steps for subsequent aerobic degradation in order to meet discharge norms and reach purification efficiencies required by national regulations (Beltran-Heredia et al., 2000a; Beltran-Heredia et al., 2000b; Beltran-Heredia et al., 2000c; Beltrán de Heredia et al., 2001d; Beltrán de Heredia et al., 2001a; Beltrán de Heredia et al., 2001b; Benitez et al., 2003).

The figure 3 shows the results obtained in experiments carried out on the wastewater of black ripe table olives which foresaw only the aerobic biologic treatment (1), the only treatment by ozone (2), the treatment by ozone followed by a aerobic biologic treatment (3), the aerobic biologic treatment followed by the ozone treatment (4).

Figure 3 shows that the biologic treatment is more efficient in order to reduce the COD, while the ozone is more efficient in the reduction of the polyphenols. The two treatments 
employed one after the other allow to bring down almost $90 \%$ of COD and polyphenols. The wastewater treated are odorless, uncolored and disinfected. They could be reintroduced into another productive loop.

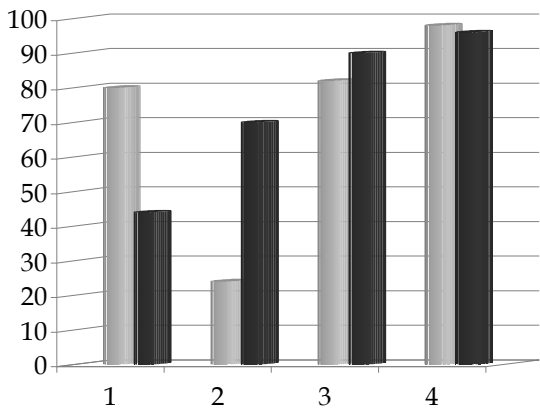

\% Reduction COD — \% Reduction Total Polyphenols

Source: Beltran-Heredia, 2001

Fig. 3. Results obtained by ozone treatment on the wastewater of black ripe table olives

Instead of to eliminate the polyphenols from the washing water, an alternative washing process could be that which foresee the recovery of the substances useful from an economic point of view (e. g. hydroxytyrosol) (De Castro \& Brenes, 2001; Bouaziz et al., 2008).

A similar proposal, but referred to the exhausted lyes deriving from the deamarization phase of the various table olive processing methods, is in the research project of D' Annibale et al. "New technology in virgin olive oil mechanical extraction process in relationship with the possible traceability and nutritional and sensory quality of oil and exploitation of vegetation waters and pomaces by recovery the bioactive products" (D'Annibale et al., 2005). This proposal is enriched from the proposition to produce enzymes from brines in order to create an economic interest. When, for various reasons, it is impossible to apply some wastewater depuration treatment able to bring down the pollution in order to dispose of it in agreement with laws, in the warm regions in which the weather is windy and there is drought, an extreme remedy could be the lagoon. In this case great attention should be given to the bad smells and leaching risk. The evaporation can be increased, favouring the absorption of the sun radiation into the lagoon basin (Chatzisymeon et al., 2008), by using surfactant agents, re-circle and spraying.

\section{Life Cycle Assessment (LCA) methodology to assess the impact of wastewater of table olives industries}

\subsection{About Life Cycle Assessment}

The LCA (Life Cycle Assessment), is a valuable analysis tool, potentially applicable to any product, process or service, and it is subject to specific standards by the International Standardization Organization (ISO). The rules of the ISO 14040 series of the Environmental Management Life Cycle Assessment (four standards dedicated each one to a specific part of 
the methodology), it is the point of reference for the application, in business decisions, of this environmental management methodology (ISO 14040, 2006; ISO 14044; ISO /TR 14048). The LCA can be used as a technical tool to identify and assess opportunities to reduce the environmental effects associated with specific products, production processes, packaging, materials or activities or to identify various scenarios on which to make strategic choices. This tool can also be used to achieve a sustainable management of the natural resources. This methodology, adopting a systemic approach, can be used as tool of private or public decisions in the various productive choices during a definition of environmental standards, to establish the basis of information from a single stage of the production process up to chain, to identify "process hot spots", as a product certification tool (for example Eco-label).

The LCA, considers the product as a system, that is analyzing the changes and flows of matter and energy, since their withdrawal from national system, that of production of the product, until the final disposal.

Numerous LCA studies were focused on the olive oil chain (Notarnicola et al., 2004; Olivieri et al., 2007; Raggi et al., 2000; Olivieri et al., 2005; Russo et al., 2008), but not many on the table olive chain (Cappelletti et al., 2010), however each business reality presents different characteristics (Salomone et al., 2010).

\subsection{The goal and scope definition}

The Life Cycle Assessment methodology was applied to the various methods used to process green and black table olives.

As for the green table olives the processes analysed were: Spanish- style, Castelvetrano-style and Green natural-style, while, as far as the black table olives, two methods of the California black ripe olives were studied (Russo et al., 2010). This analysis aims to highlight the contribution, of the wastewater produced from each processing method, to the totally environmental burden referred to the table olives industries. For this reason the system boundaries were simplified including only the sub-phases referred to the processing methods. In order to better focusing the study on the industrial phase, the agricultural phase and packaging were excluded from the analysis. The Functional Unit (FU) chosen was 100 $\mathrm{kg}$ of fresh table olives.

\subsection{The Life Cycle Inventory (LCI)}

As for the input and output concerning the processing methods, all the relevant data were considered. Although in different quantity, Spanish-style (figure 4) and Castelvetrano-style (figure 5) have the same input, while the input of green natural-style (figure 8) are quite different for quantity and type respect to these of the other methods used to processing green table olives. As for the methods used to processing black olives, the two methods of California black ripe olives present same input (figure 6 and 7), but also in this case the amount is not the same. As for the output, the amount of waste are the same for the green olives processes and quite high for the two methods of California black ripe olives. As far as the wastewater, figure 9 shows the quantity produced by each processing methods; among the various processes, the method $\mathrm{B}$ of the California black ripe olives produces the greater amount of wastewater, almost $9 \mathrm{~kg}$ per $\mathrm{kg}$ of fresh raw material. This is due to the lower quantity of caustic soda used respect the method A and the higher number of washes needed to oxidizing the olives and fixing their black colour. 


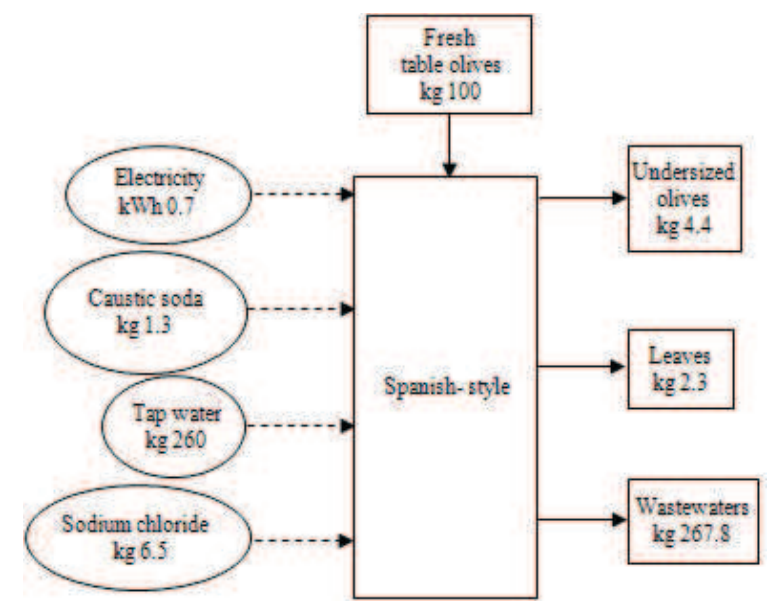

Fig. 4. Layout of Spanish-style

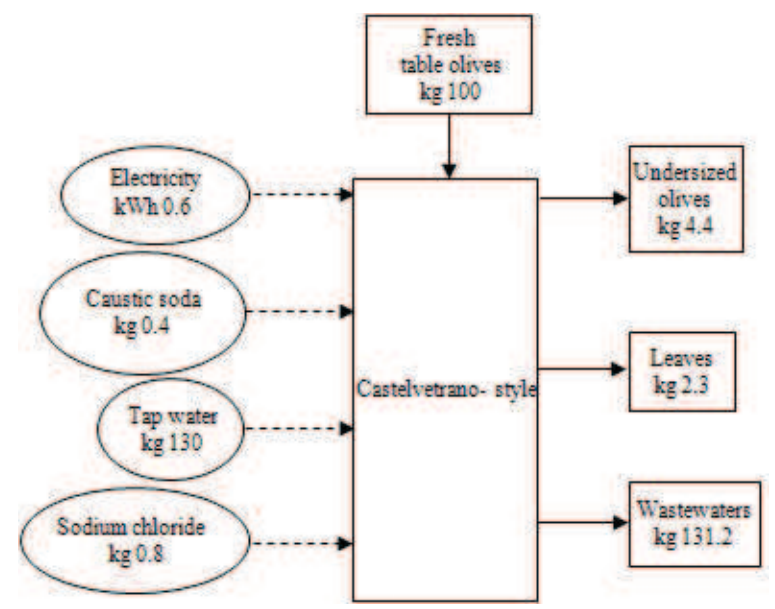

Fig. 5. Layout of Castelvetrano-style 


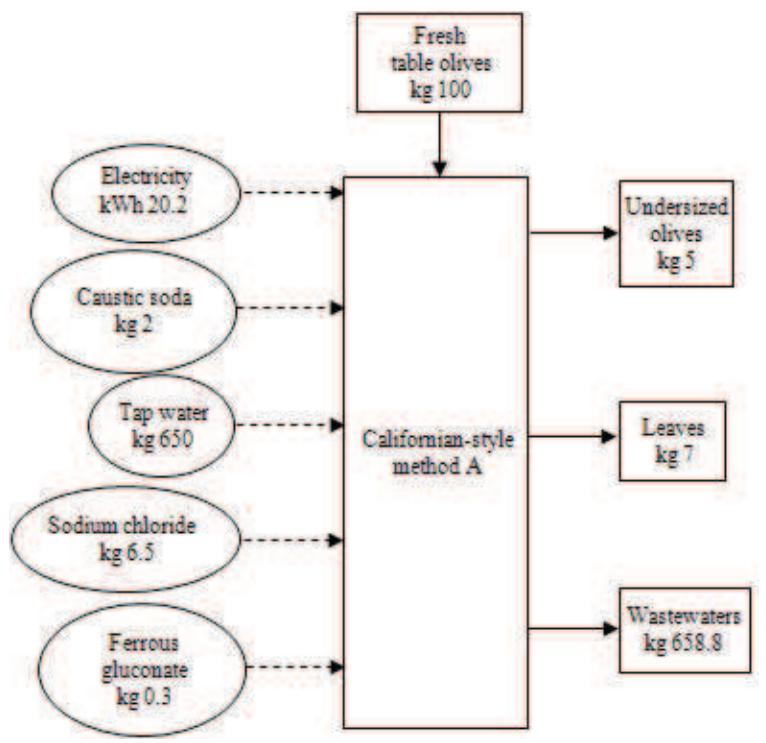

Fig. 6. Layout of California black ripe olives method A

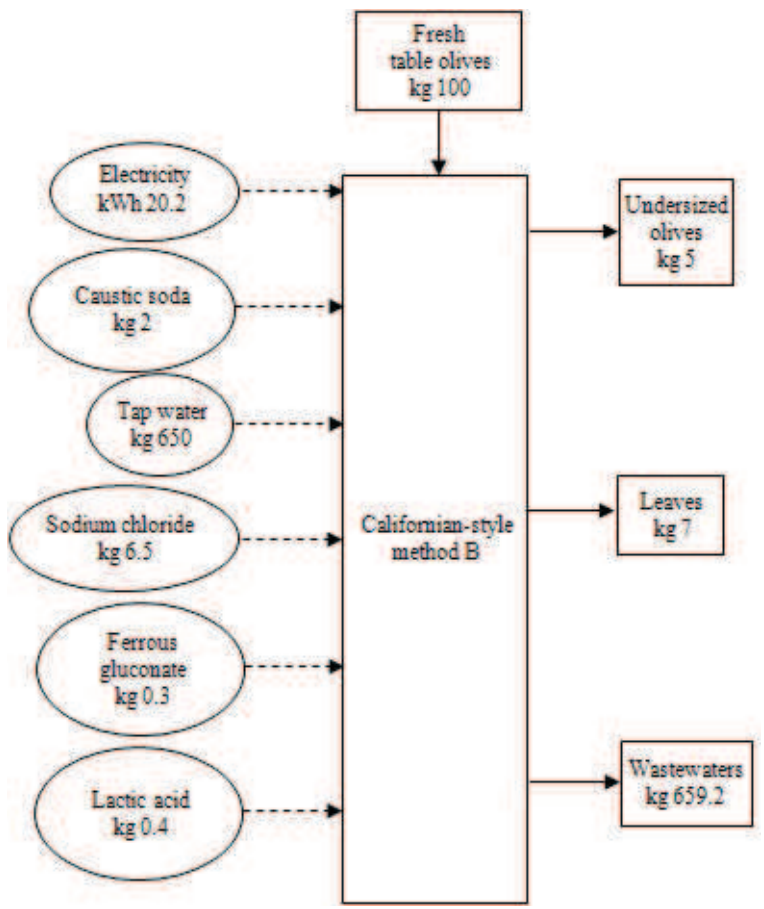

Fig. 7. Layout of California black ripe olives method B 


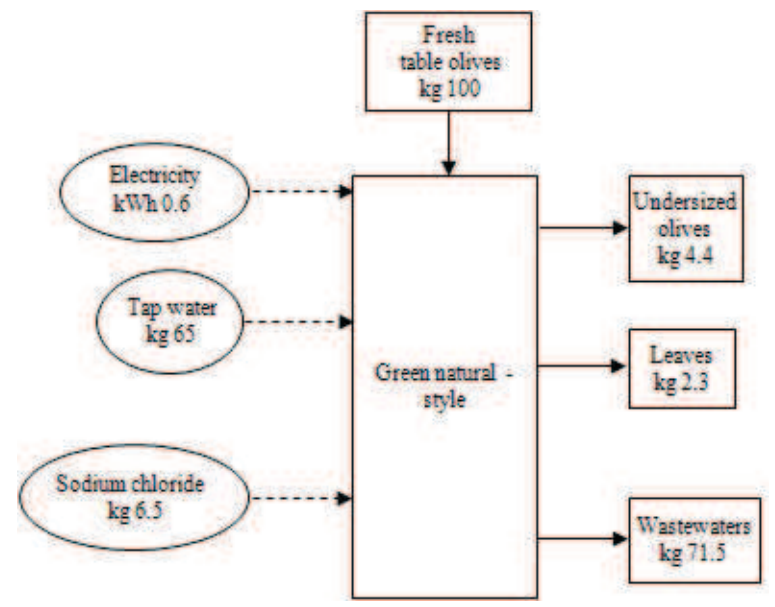

Fig. 8. Layout of the green natural-style

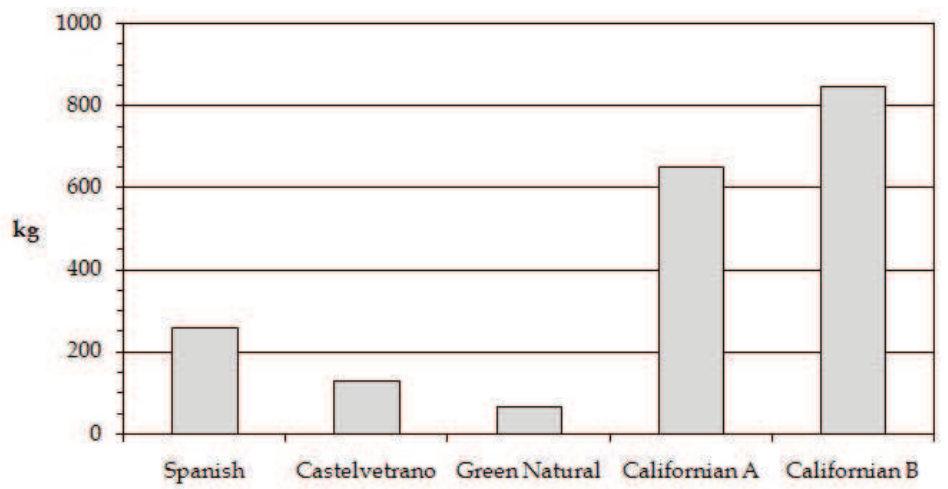

Fig. 9. Wastewater referred to $100 \mathrm{~kg}$ of processed table olives, distinguishing among the various manufacturing processes

In order to better compare the amount of materials and energy and the waste produced by the processing methods considered, table 13 shows, for each one, the amount of all the input and output. In particular, as for the wastewater, these are distinguished for each sub-phases. Among the methods used to processing green olives, the Spanish-style is the one that needs the higher amount of water, electricity and caustic soda, while comparing all the processes, the method B of the California black ripe olives needs more quantity for almost all the input (exception for caustic soda, employed in higher quantity in the California black ripe olives method A). Focusing the attention on the production of wastewater, table 1 shows that, exception for the green natural style, the sub-phase in which wastewater are produced in greater quantity is the washing phase. It is due to the need to eliminate the residues of caustic soda after the deamarization phase. The green natural-style don't employ caustic soda because of the deamarization take place in a solution of water and salt and after the olives don't need to be washed, but this method take a long time and not for all the variety of table olives is convenient from an economic point of view. 


\begin{tabular}{|c|c|c|c|c|c|c|}
\hline \multirow[b]{2}{*}{ Input } & & \multicolumn{3}{|c|}{ Green table olives } & \multicolumn{2}{|c|}{ Black table olives } \\
\hline & & $\begin{array}{l}\text { Spanish } \\
\text { style }\end{array}$ & $\begin{array}{l}\text { Castelvetrano } \\
\text { style }\end{array}$ & $\begin{array}{c}\text { Green } \\
\text { Natural } \\
\text {-style }\end{array}$ & $\begin{array}{c}\text { California } \\
\text { black ripe } \\
\text { olives } \\
\text { method A }\end{array}$ & $\begin{array}{c}\text { California } \\
\text { black ripe } \\
\text { olives } \\
\text { method B }\end{array}$ \\
\hline Water & $\mathrm{kg}$ & 260.0 & 130.0 & 65.0 & 650.0 & 845.0 \\
\hline Electricity & $\mathrm{kWh}$ & 0.7 & 0.6 & 0.6 & 20.2 & 27.3 \\
\hline $\begin{array}{l}\text { Sodium chloride } \\
\mathrm{NaCl}\end{array}$ & $\mathrm{kg}$ & 6.5 & 0.8 & 6.5 & 6.5 & 6.5 \\
\hline Lactic Acid & $\mathrm{kg}$ & & & & & 0.4 \\
\hline Caustic Soda $\mathrm{NaOH}$ & $\mathrm{kg}$ & 1.3 & 0.4 & & 2.0 & 1.3 \\
\hline Ferrous Gluconate & $\mathrm{kg}$ & & & & 0.3 & 0.3 \\
\hline \multicolumn{7}{|l|}{ Output } \\
\hline $\begin{array}{l}\text { Undersized Olives } \\
\text { and Leaves }\end{array}$ & $\mathrm{kg}$ & 6.7 & 6.7 & 6.7 & 12.0 & 12.0 \\
\hline $\begin{array}{l}\text { WW Preservation in } \\
\text { Brine }\end{array}$ & $\mathrm{kg}$ & & & & 71.5 & 71.5 \\
\hline WW Deamarization & $\mathrm{kg}$ & 66.3 & 66.2 & 71.5 & 197.0 & 66.3 \\
\hline WW Washes & $\mathrm{kg}$ & 130.0 & 65.0 & & 325.0 & 650.0 \\
\hline WW Fermentation & $\mathrm{kg}$ & 71.5 & & & & \\
\hline $\begin{array}{l}\text { WW Ferrous } \\
\text { gluconate attack }\end{array}$ & $\mathrm{kg}$ & & & & 65.3 & 65.3 \\
\hline
\end{tabular}

Table 13. Input and output referred to the various table olives manufacturing processes

\subsection{Data quality}

The inventory data was collected from various sources. The data concerning the input of technological processing was collected directly from processing companies which produce green table olives, by using Spanish-style, and black-ripe table olives, by using California black ripe olives method $\mathrm{A}$ and $\mathrm{B}$. Electricity consumption was measured, as well as the amount of input resources and wastewater. For what concerning the green natural-style and Castelvetrano-style, also some data coming from literature was considered (GarridoFernandez et al., 1997). As far as electricity production, the Italian mix was the type considered (AEEG, 2010). As far as the issues of wastewater; by means of laboratory analyses we assessed the pollution caused by the exhausted brines, lyes and washing waters referred to the Spanish-style and California black ripe olives, while for green natural-style and Castelvetrano-style we considered literature data. All collected data was processed by using GaBi4 software and its databases (IKP and PE, 2002), also Ecoinvent database was used (Frischknecht et al., 2004).

\subsection{LCIA (Life Cycle Impact Assessment)}

The CML 2001 impact assessment method was used to analyse the environmental impact of the input and output measured during the inventory phase. The categories of pollution considered by this method were: abiotic depletion potential (ADP), acidification potential 
(AP), eutrophication potential (EP), freshwater aquatic ecotoxicity potential (FAETP inf.), global warming potential (GWP 100 years), human toxicity potential (HTP), marine aquatic ecotoxicity potential (MAETP), ozone layer depletion potential (ODP, steady state), photochemical ozone creation potential (POCP), radioactive, radiation (RAD) and terrestric ecotoxicity potential (TETP). All these impact categories were opportunely weighted and normalized in order to obtain an eco-indicator.

Figure 10 shows, for each processing method, the value of the CML 2001 eco-indicator deriving from the sum of the normalized value of the impact categories. As for the methods used to processing green olives, the category EP is the most important, while as far as the California black ripe olives the category that mainly contribute to the total eco-indicator is MAETP, but also EP and GWP increase the value. This is due to the impact deriving from the greater use of the electricity required to oxidize the olives and fixing their black colour.

CML 2001 eco-indicator

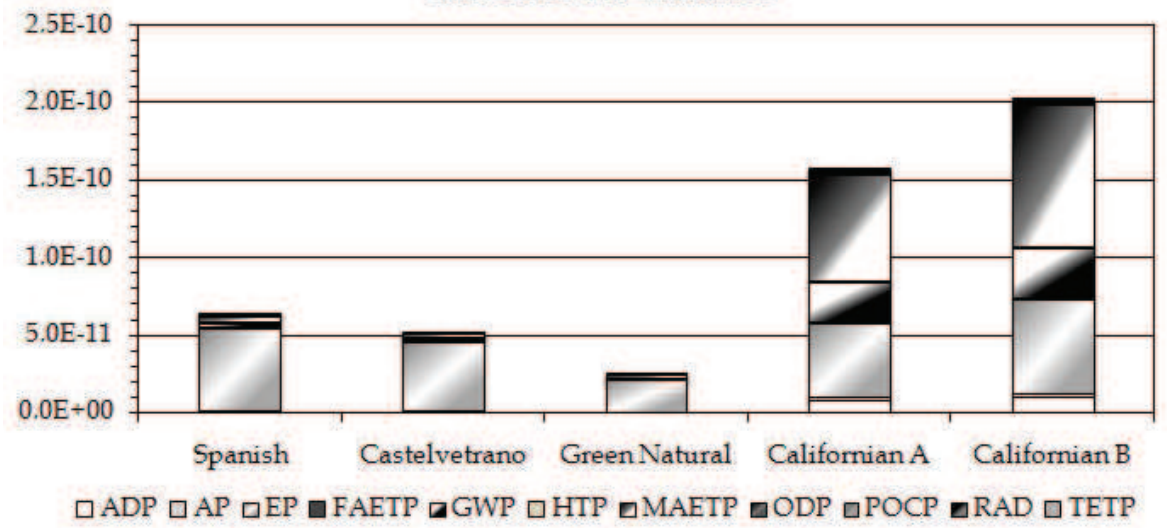

Fig. 10. Eco-indicator referred to the various table olives manufacturing processes

The LCA results underlined that the eutrophication is a very important impact for the table olives processing industries, and it derives from the pollution of the wastewater. In order to better understand the pollution of the wastewater of table olives industries, figure 11, shows, for each processing method the contribution to the eutrophication of the wastewater produced in the different sub-phases of the process.

By analysing the Spanish-style, the exhausted brine is more pollutant than lye, while, even though the washing waters are greater in volume, they are the less pollutant, the deamarization phase of the Castelvetrano-style is quite different from that of Spanish-style because sodium chloride is added to the lye, in order to accelerate the deamarization process, so, as shown in figure 11, the wastewater from this phase have higher environmental burdens, the washing waters further affect the eutrophication, but the total value is lower than the one referred to the Spanish-style.

As for green natural style, the process don't foresee washes but only deamarization in brine, so the wastewater produced in this phase are the only contributor to the EP and their pollution, among all the processes analysed is the lowest.

By analysing the California black ripe olives, figure 11 shows that as for the EP an important contribution is due to the wastewater deriving from the phase of preservation in brine, also the washing waters heavily contribute to the total EP, especially in the method B, while the 


\section{Eutrophication Potential}

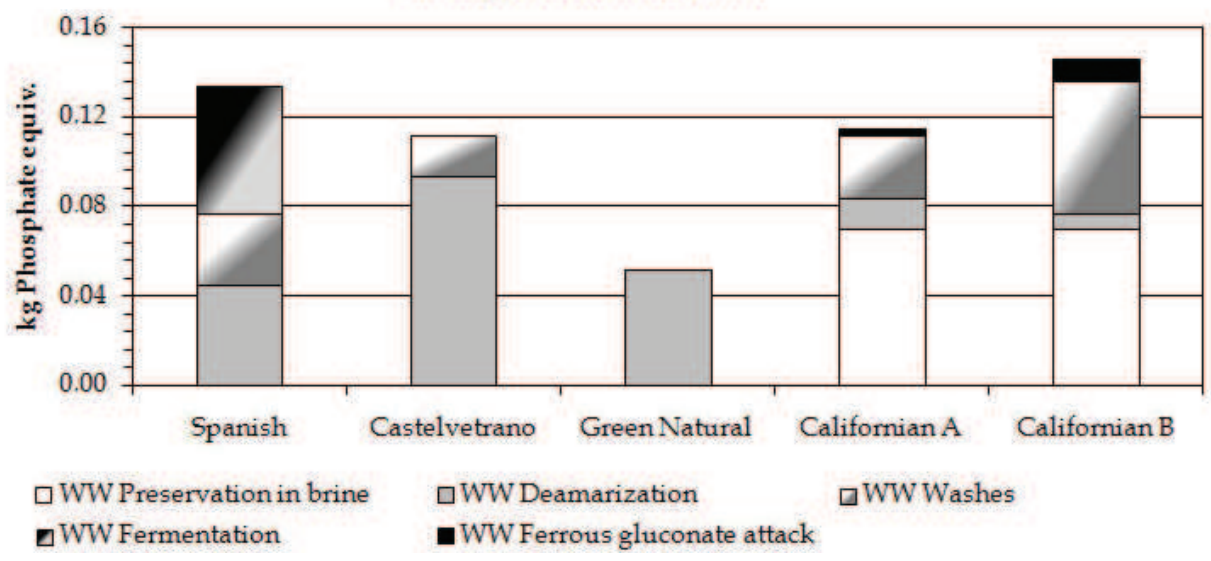

Fig. 11. Eutrophication Potential, distinguishing among the various table olives manufacturing processes

exhausted lyes and the wastewater deriving from the phase of ferrous gluconate attack present a low environmental impact.

Finally, even though the processes compared make use of different technologies to obtain end products each with distinct organoleptic characteristics, we can state that "Green natural style" processing gives a better environmental performance in terms of eutrophication potential and the California black ripe olives method B appears to be the most polluting overall, but it is relevant to point out that method A of California black ripe olives has a lower EP value than Spanish-style.

\subsection{Improvement hypothesis}

The Life Cycle Assessment has highlighted that the wastewater is an important issues deriving from table olives industries, and the impact category mainly affected by the pollution of wastewater is the eutrophication. Among the various processing methods used to process green and black table olives, wastewater are produced in different amount and affect in different way the impact category EU.

In order to improve the environmental performance of these processing-system, however, technological solutions could be adopted with the aim of reducing the amount of material used (caustic soda, sodium chloride, water), and consequently limit the negative effects connected to its production and use (Marsilio et al., 2008). It is also worth considering reusing the brine and the rinsing-water, in order to reduce the amount of wastewater produced and the emissions (Segovia-Bravo et al., 2008). An important improving solution could be also represented from the extraction of the useful substances, such as phenols, responsible to the high pollution of the wastewater (De Castro et al., 1983; GarridoFernandez, 1983; Garrido Fernandez et al., 1997; Bouaziz et al., 2008). Finally, especially for the Californian methods that use greater amount of electricity, environmental improvement should concern also the minimizing of the impacts deriving from energy production. This objective could be achieved by, e.g., installing renewable energy sources at the factory in order to use the electricity directly for these uses. It is important to consider that the 
adoption of these solution made with regard to achieving the objectives of eco-compatibility, leads to advantages, which are not only environmental (a lower consumption of resources, a reduction in pollutants etc.) but also economic (i.e. lower costs).

\section{Contribution of authors}

This paper has been thought, discussed and written by the three authors and it is the result of their common commitment, in particular Giulio Mario Cappelletti has contributed to paragraphs 1 and 2; Giuseppe Martino Nicoletti has contributed to paragraphs 3 and 4; Carlo Russo has contributed to paragraph 5.

\section{References}

AEEG, www.autorita.energia.it (Website consulted Sep 2010).

Amelio, M. \& De Muro, E. (2000). Naturally fermented black olives of Taggiasca variety (Olea europaea L.). Grasas y Aceites, 51, 6, 429-439.

Arroyo-López, F.N.; Querol, A. ; Bautista-Gallego, J. \& Garrido-Fernández, A. (2008). Role of yeasts in table olive production. International Journal of Food Microbiology, 128, 2, 189-196.

Beltran-Heredia, J.; Torregrosa, J.; Dominguez, J. R. \& Garcia, J. (2000a). Treatment of blackolive wastewaters by ozonation and aerobic biological degradation. Water Research, $34,14,3515-3522$.

Beltran-Heredia, J.; Torregrosa, J.; Dominguez, J. R. \& Garcia, J. (2000b). Ozonation of blacktable-olive industrial wastewaters: effect of an aerobic biological pretreatment. Journal of Chemical Technology \& Biotechnology, 75, 7, 561-568.

Beltran-Heredia, J.; Torregrosa, J.; Dominguez, J. R. \& Garcia, J. (2000c). Aerobic biological treatment of black table olive washing wastewaters: effect of an ozonation stage. Process Biochemistry, 35, 1183-1190.

Beltràn, F. J. ; Rivas, F. J. ; Gimeno, O. \& Frades, J. (2000d). Wet air oxidation of wastewater from table olive elaboration industries, Proceedings of the Symposia of the Division of Environmental Chemistry of the American Chemical Society, San Francisco (CA), March 26-30.

Beltrán de Heredia, J. A.; Torregrosa, J. A.; Vargas, J. R. D. \& Garcìa Rodrìguez, J. (2001a). Depuración de las aguas de lavado de aceitunas negras mediante procesos biológico aerobio y de ozonización. Grasas y Aceites, 52, 3-4, 184-191.

Beltrán de Heredia, J.; Torregrosa, J.; Domínguez, J. R. \& García, J. (2001b). Tratamiento con ozono de lejías residuales del aderezo de aceitunas negras. Grasas y Aceites, 52, 1, $17-25$.

Beltran, J.; Gonzalez, T. \& Garcia, J. (2008). Kinetics of the biodegradation of green table olive wastewaters by aerobic and anaerobic treatments. Journal of Hazardous Materials, 154, 1-3, 839-845.

Benitez, J. F.; Acero, J. L. \& Leal, A. I. (2003). Purification of storage brines from the preservation of table olives. Journal of Hazardous Materials, B, 96, 155-169.

Bouaziz, M.; Lassoued, S.; Bouallagui, Z. , Smaoui, S.; Gargoubi, A.; Dhouib, A. \& Sayadi, S. (2008). Synthesis and recovery of high bioactive phenolics from table-olive brine process wastewater. Bioorganic \& Medicinal Chemistry, 16, 9238-9246. 
Brenes, M.; Garcìa, P.; Romero Concepciòn \& Garrido, A. (2000). Treatment of green table olive wastewaters by an activated-sludge process. J. Chem. Tech. Biotech., 75, 6, 459463.

Brenes, M. (2004). Olive Fermentation and processing: scientific and technological challenges. Journal of Food Science, 69, 1, FMS33-FMS34.

Brenes, M. \& García, P. (2005). Elaboración de aceitunas denominadas «Green ripe olives» con variedades españolas. Grasas y Aceites, 56, 3, 188-191.

Brighigna, A. (1998). Le Olive da tavola, Edizioni agricole, Bologna, Italy, 1998.

Cappelletti, G. M. ; Nicoletti, G. M. \& Russo, C. (2010). Life Cycle Assessment (LCA) of Spanish-style green table olives. Italian Journal of Food Science, 22, 1, 3-14.

Chatzisymeon, E.; Stypas, E.; Bousios, S.; Xekoukoulotakis, N. P. \& Mantzavinos, D (2008). Photocatalytic treatment of black table olive processing wastewater. Journal of Hazardous Materials, 154, 1090-1097.

D'Annibale, A. et al. (2005). New technology in virgin olive oil mechanical extraction process in relationship with the possible traceability and nutritional and sensory quality of oil and exploitation of vegetation waters and pomaces by recovery the bioactive products (retrieved from http://www.ricercaitaliana.it/prin/dettaglio_prin_en-2005070135.htm)

De Castro, G. M. ; Duran Quintana, M. C. ; Garcia Garcia, P., et al. (1983). Processing fruits of «Gordal» variety, without washing and reusing lye solutions, as Spanish style green style olives. Wastewaters study and some purification tests. Grasas y Aceites, $3,162$.

De Castro, A. \& Brenes, M. (2001). Fermentation of washing waters of Spanish-style green olive processing. Process Biochemistry, 36, 797-802.

Deligiorgis, A.; Xekoukoulotakis, N. P.; Diamadopoulos, E. \& Mantzavinos, D. (2008). Electrochemical oxidation of table olive processing wastewater over boron-doped diamond electrodes: Treatment optimization by factorial design. Water Research, 42, 1229-1237.

Frischknecht, R. \& Jungbluth, N. (2007). Overview and Methodology, In: Ecoinvent report No. 1, Frischknecht, R. \& Jungbluth, N. (Ed.), Dübendorf, Switzerland.

Garrido Fernandez, A. (1983). Study of ripe olive wastewaters and their reusing possibilities. Grasas y Aceites, 5, 317.

Garrido Fernàndez, A. \& Fernàndez Diez, M. J. (1997). Table olives, production and processing. Chapman \& Hall, London, UK, 1997.

Gomez, A. H. S.; Garcia, P. \& Navarro, L. R. (2006). Elaboration of table olives. Grasas y Aceites, 57, 1, 86-94.

Hernandez, A.; Martin, A.; Aranda, E.; Perez-Nevado, F. \& Cordoba, M. G. (2007). Identification and characterization of yeast isolated from the elaboration of seasoned green table olives. Food Microbiology, 24, 4, 346-351.

Higinio Sánchez Gómez, A.; García García, P. \& Rejano Navarro, L. (2006). Elaboration of table olives. Grasas y Aceites, 57, 1, 86-94.

IKP, PE (2002). GaBi 4 - Software-system and databases for life cycle engineering. Stuttgart, Echterdingen. Germany.

ISO 14040. (2006). Environmental management - Life cycle assessment - Principles and framework (ISO 14040:2006), International Standard, Geneva, ISO. 
ISO 14044. (2006). Environmental management - Life cycle assessment - Requirements and guidelines (ISO 14044:2006), International Standard. Geneva, ISO.

ISO/TS 14048. (2006). Environmental management - Life cycle assessment - Data Documentation Format. (ISO/TS 14048: 2006), International Standard. Geneva, ISO.

Javier Casado, F; Antonio Higinio Sánchez, A.; Rejano, L. \& Montaño, A. (2007). Estudio de nuevos procedimientos de elaboración de aceitunas verdes tratadas con álcali, no fermentadas, conservadas mediante tratamientos térmicos. Grasas y Aceites, 58, 3, 275-282.

Javier Casado, F.; Higinio Sánchez, A.; Rejano, L.; de Castro, A. \& Montaño, A. (2010). Stability of sorbic and ascorbic acids in packed green table olives during long-term storage as affected by different packing conditions, and its influence on quality parameters. Food Chemistry, 122, 3, 812-818.

Kanavouras, A.; Gazouli, M.; Tzouvelekis Leonidas, L. \& Petrakis, C. (2005). Evaluation of black table olives in different brines. Grasas y Aceites, 56, 2, 106-115.

Katsoni, A.; Frontistis, Z.; Xekoukoulotakis, N. P.; Diamadopoulos, E. \& Mantzavinos, D. (2008). Wet air oxidation of table olive processing wastewater: determination of key operating parameters by factorial design. Water research, 42, 3591-3600.

Kotsou, M.; Kyriacou, A.; Lasaridi, K. \& Pilidis, G. (2004). Integrated aerobic biological treatment and chemical oxidation with Fenton's reagent for the processing of green table olive wastewater. Process Biochemistry, 39, 11, 1653-1660.

Marsilio, V.; Campestre, C. \& Lanza, B. (2001). Sugar and polyol compositions of some European olive fruit varieties (Olea europaea L.) suitable for table olive purposes. Food Chemistry, 72, 4, 485-490.

Marsilio, V. ; Russi, F. ; Iannucci, E. \& Sabatini, N. (2008). Effects of alkali neutralization with $\mathrm{CO}_{2}$ on fermentation, chemical parameters and sensory characteristics in Spanishstyle green olives (Olea europaea L.). LWT - Food Science and Technology, 5, 796.

Notarnicola, B.; Tassielli, G. \& Nicoletti, G. M. (2004). LCC and LCA of extra-virgin olive oil: organic vs. conventional. Life Cycle Assessment in the Agri-food sector, Proceeding from the 4th International Conference "Life Cycle Assessment in the Agri-food sector:, pp. 289-293, Horsens, Denmark, Danish Institute of Agricultural Sciences (DIAS), October 6-8 2003, Retrieved from http://www.lcafood.dk/lca_conf/DJFrapport_paper_2_poster.pdf

Olivieri, G. ; Falconi, F. ; Pergreffi, R. ; Neri, P. \& Romani, A. (2005). Life Cycle Assessment for environmental integrated system in the olive oil tuscan company. European Meeting of the International Society for Industrial Ecology, pp. 127-130, Bologna, Italy 10-11 January 2005, printed by Setac.

Olivieri, G. ; Neri, P. ; Bandini, F. \& Romani, A. (2007). Life Cycle assessment of Tuscany olive oil production, Proceedings of The AGS Annual Meeting, Barcelona, Spain. 2007.

Quintana, M. C. D.; Barranco, C. R. \& Garcia, P. G. (1997). Lactic acid bacteria in table olive fermentations. Grasas y Aceites, 48, 5, 297-311.

Raggi, A. ; Cichelli., A. ; Pagliuca, G. \& Costantino, A. (2000). A screening LCA of olive husk combustion for residential heating, 1st World Conference on Biomass for Energy and Industry, pp 1001-1004, Sevilla, Spain, 5-9 June 2000, James \& James (Science Publishers) Ltd. 
Romeo, F. V.; De Luca, S; Piscopo, A.; Perri, E. \& Poiana, M. (2009). Effects of postfermentation processing on the stabilisation of naturally fermented green table olives (cv. Nocellara etnea). Food Chemistry, 116, 4, 873-878.

Russo, C. ; Cappelletti, G. M. \& Nicoletti, G. M. (2008). LCA of Energy Recovery of the Solid Waste of the Olive Oil Industries, 6th International Conference on Life Cycle Assessment in the Agri-Food Sector "Towards a Sustainable Management of the Food Chain" Zurich, Switzerland, November 12-14, 2008, Retrieved from: http://www.agroscope.admin.ch/aktuell/02720/02722/03985/index.html?lang=de

Russo, C. ; Cappelletti, G. M. \& Nicoletti, G. M. (2010). Life Cycle Assessment (LCA) used to compare two different methods of processing ripe table olives. Grasas y Aceites, 61, 2, 136-142.

Salomone, R. ; Cappelletti, G. M. ; Ioppolo, G. ; Mistretta, M. ; Nicoletti, G. M. ; Notarnicola, B. ; Olivieri, G. ; Pattara, C. ; Russo, C. \& Scimia, E. (2010). Italian experiences in Life Cycle Assessment of olive oil: a survey and critical review, Proceeding of the 7 th International Conference on Life Cycle Assessment in the Agri-Food Sector", pp. 265:270, Bari, Italy, September 22-24, 2010.

Segovia-Bravo, K. A.; Garcia-Garcia, P.; Arroyo-Lòpez, F. N.; Lòpez-Lòpez, A. \& GarridoFernàndez, A. (2008). Ozonation process for the regeneration and recycling of Spanish green table olive fermentation brines. Eur Food Res Technol, 227, 463-472.

Unal, K. \& Nergiz, C. (2003). The effect of table olive preparing methods and storage on the composition and nutritive value of olives. Grasas y Aceites, 54, 1, 71-76.

www.internationaloliveoil.org (Website consulted Sep 2010). 


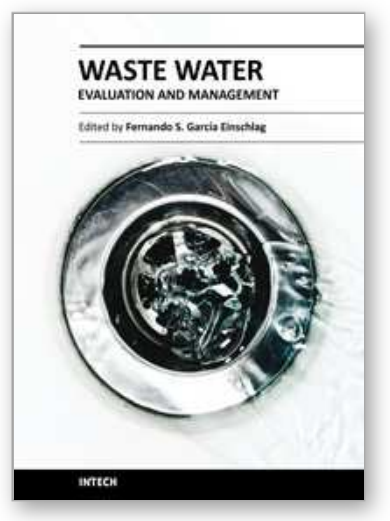

\author{
Waste Water - Evaluation and Management \\ Edited by Prof. Fernando Sebastiã $i n$ GarcÃa Einschlag
}

ISBN 978-953-307-233-3

Hard cover, 470 pages

Publisher InTech

Published online 01, April, 2011

Published in print edition April, 2011

Fresh water resources are under serious stress throughout the globe. Water supply and water quality degradation are global concerns. Many natural water bodies receive a varied range of waste water from point and/or non point sources. Hence, there is an increasing need for better tools to asses the effects of pollution sources and prevent the contamination of aquatic ecosystems. The book covers a wide spectrum of issues related to waste water monitoring, the evaluation of waste water effect on different natural environments and the management of water resources.

\title{
How to reference
}

In order to correctly reference this scholarly work, feel free to copy and paste the following:

G.M. Cappelletti, G.M. Nicoletti and C. Russo (2011). Wastewater from Table Olive Industries, Waste Water Evaluation and Management, Prof. Fernando SebastiÃ $i n$ GarcÃa Einschlag (Ed.), ISBN: 978-953-307-233-3, InTech, Available from: http://www.intechopen.com/books/waste-water-evaluation-andmanagement/wastewater-from-table-olive-industries

\section{INTECH}

open science | open minds

\section{InTech Europe}

University Campus STeP Ri

Slavka Krautzeka 83/A

51000 Rijeka, Croatia

Phone: +385 (51) 770447

Fax: +385 (51) 686166

www.intechopen.com

\section{InTech China}

Unit 405, Office Block, Hotel Equatorial Shanghai

No.65, Yan An Road (West), Shanghai, 200040, China

中国上海市延安西路65号上海国际贵都大饭店办公楼 405 单元

Phone: +86-21-62489820

Fax: +86-21-62489821 
(C) 2011 The Author(s). Licensee IntechOpen. This chapter is distributed under the terms of the Creative Commons Attribution-NonCommercialShareAlike-3.0 License, which permits use, distribution and reproduction for non-commercial purposes, provided the original is properly cited and derivative works building on this content are distributed under the same license. 